\title{
Influence of the Oxide and Ethanol Surface Layer on Phase Transformation of Al-Based Nanocomposite Powders under High-Energy Milling
}

\author{
Dora Janovszky \\ MTA-ME Materials Science Research Group, Miskolc, Hungary; fekjd@uni-miskolc.hu
}

Received: 28 March 2019; Accepted: 19 April 2019; Published: 21 April 2019

\begin{abstract}
Pure Al particles reinforced with amorphous-nanocrystalline $\mathrm{Cu}_{36} \mathrm{Zr}_{48} \mathrm{Ag}_{8} \mathrm{Al}_{8}$ particles composite powders were prepared by high-energy milling without and with ethanol. The mechanical milling procedures were compared so that in the case of dry milling the particle size increased owing to cold welding, but the crystallite size decreased below $113 \mathrm{~nm}$. The amorphous phase disappeared and was not developed until $30 \mathrm{~h}$ of milling time. Using ethanol as a process control agent, the particle size did not increase, while the amorphous fraction increased to $15 \mathrm{wt} . \%$. Ethanol decomposed to carbon dioxide, water, and ethane. Its addition was necessary to increase the amount of the amorphous structure.
\end{abstract}

Keywords: high-energy milling; Al-based composite; process control agent; amorphous-nanostructure alloy; dry and wet grinding

\section{Introduction}

The demand for Al-based metal matrix composites (AMMCs) will continue increasing at unstoppable rates due to development in the automotive and construction industry. Improvement in the strength of aluminum alloys can be achieved by uniformly distributed hard materials such as oxides [1,2], borides [3], carbides [4], graphene [5,6] or carbon nanotubes [7,8]. However, wetting problems arise and microparticles severely degrade the plasticity and machinability of metals [9]. The introduction of metallic particles, particularly amorphous-nanocrystalline alloy, can solve these problems owing to their high strength, large elastic limit, high corrosion resistance, and good wettability by the metal matrix $[10,11]$. The powder metallurgical route can be successfully employed to fabricate an amorphous/nanocrystalline composite powders in which the reinforcing particles are uniformly distributed in the Al- matrix. In the case when one mills two different metallic powders, several solid phase transformations take place [12-15]. A process control agent (PCA) such as stearic acid, benzene, methanol, or ethanol is added to the powder mixture during milling to reduce the effect of cold welding between powder particles [16-18]. The PCA adsorbs on the surface of the powder particles and minimizes cold welding between powder particles and thereby inhibits agglomeration $[19,20]$. Furthermore, the PCA has a significant effect on the milling process [21,22]. Nowadays, the exact mechanism of different PCAs during high-energy milling and their influence on the outcome is not known. It is also unclear what organic additive is the best for each material. A large variety of PCAs was used in mechanical alloying experiments. In some Fe containing powder milling, it was found that the presence of organic PCA, except ethanol, was necessary for the formation of the amorphous phase. This fact was explained by the dissolution of $\mathrm{C}$ atoms from PCA in the Fe-B phase by mechanical milling $[18,23]$. The role of ethanol in the formation of amorphous structure is not clear during high-energy milling of the $\mathrm{Al}$ matrix powders either. 
In this work, the influence of oxygen and ethanol on the outcome of the high-energy milling process of an Al-based composite is presented. Amorphous-nanocrystalline $\mathrm{Cu}_{36} \mathrm{Zr}_{48} \mathrm{Ag}_{8} \mathrm{Al}_{8}$ alloy was chosen as a reinforcing component in the form of powder. The high-energy milling process was investigated with and without ethanol as the PCA.

\section{Material and Methods}

Centrifugal cast rods with the atomic composition $\mathrm{Cu}_{36} \mathrm{Zr}_{48} \mathrm{Ag}_{8} \mathrm{Al}_{8}$ (the numbers indicate at. \%) were ground and fractionated to a particle size below $320 \mu \mathrm{m}$ for ball-milling. The amorphous content of the ground powder was approximately $12 \mathrm{wt} . \%$ based on X-ray diffraction (XRD, Bruker Gmbh, Berlin, Germany) analysis. Pure Al powder ( $99.5 \mathrm{wt} . \%$ and $15 \mu \mathrm{m}$ average particle size, $664{ }^{\circ} \mathrm{C}$ melting point) was selected as the matrix material. Al powder with $10 \mathrm{wt} . \% \mathrm{Cu}_{36} \mathrm{Zr}_{48} \mathrm{Ag}_{8} \mathrm{Al}_{8}$ particles was milled for $30 \mathrm{~h}$. The mixed powder was milled at room temperature in a Pulverisette 5 high-energy ball-mill at $200 \mathrm{rpm}$ under a protective argon atmosphere using a stainless-steel grinding bowl and steel balls of different diameters, which were used together. The diameters of the hardened balls were $20 \mathrm{~mm}, 12 \mathrm{~mm}$, and $10 \mathrm{~mm}$. Two series of experiments were carried out. In the first experiment, the weight ratio of the ball to the powder (BPR) was 10:1 (A1 experiment). To study the effect of the milling time, samples were taken between $5-30 \mathrm{~h}$ by interrupting the milling cycle in the case of the first milling experiment. A sample of $0.7 \mathrm{~g}$ was taken every $5 \mathrm{~h}$ to check the effect of the milling time on the particle size, shape, and amorphous content. In the second experiment (A2) the milling bowl was not opened until $30 \mathrm{~h}$ of milling time and some ethanol was used as the PCA. In order to avoid overheating in the vials, the milling procedure was interrupted every $60 \mathrm{~min}$ and halted for $60 \mathrm{~min}$ in both experiments.

The microstructure of the powders was examined by a Hitachi S-4800 Scanning Electron Microscope (SEM, Hitachi, Tokyo, Japan) equipped with a BRUKER AXS type energy-dispersive X-ray spectrometer (EDS). Backscattered electron micrographs were recorded in order to get information about the microstructure of the samples. The particle size distribution of the ground material was determined by a Horiba LA-950 V2 type laser diffraction particle size analyzer (Horiba Ltd., Kyoto, Japan) in distilled water. During the measurement process, 1-minute ultrasonic treatment and $1 \mathrm{~mL}$ of $50 \mathrm{~g} / \mathrm{L}$ sodium pyrophosphate dispersant were applied to achieve the appropriate dispersity state.

Thermal analysis was performed in a Netzsch 204 DSC (Netzsch Ltd., Selb, Germany) at a heating rate of $0.66 \mathrm{~K} / \mathrm{s}$ under a flow of purified argon. X-ray diffraction (XRD) phase analysis was performed by a Bruker D8 Advance diffractometer (XRD, Bruker Gmbh, Berlin, Germany) using Cu K $\alpha$ radiation $(40 \mathrm{kV}, 40 \mathrm{~mA})$, in parallel beam geometry obtained with a Göbel mirror equipped with a Vantec-1 position sensitive detector $\left(1^{\circ}\right.$ window opening), measured in the $2-100^{\circ}(2 \theta)$ angular range, at $0.007^{\circ}$ $(2 \theta) / 29 \mathrm{~s}$ speed. The specimen rotated in the sample plane during the measurement to obtain data from the whole surface and to reduce in-plane preferred orientation effects. The crystalline fraction was determined by XRD analysis using peak area determination in TOPAS4 (amorphous hump method). Quantitative results were obtained by combined use of Rietveld refinement and peak area calculation [24,25]. The volatile substances in the milling bowl were analyzed by an Agilent 7890A gas chromatograph (Agilent Technologies, Inc. Wilmington, USA) equipped with Agilent 5975C mass selective detector (Agilent Technologies, Inc., Wilmington, NC, USA) and MSD ChemStation software.

\section{Results and Discussion}

\subsection{Raw Materials}

The morphology and particle size distribution of pure Al powder is shown in Figure 1. The particle size of the irregular $\mathrm{Al}$ alloy powder, as measured by a laser diffraction particle size analyzer, spans in the range of $4-51 \mu \mathrm{m}$ (Figure $1 \mathrm{~b}$ ). The mode of $\mathrm{Al}$ powder is $14.2 \mu \mathrm{m}$. Brittle fracturing can be observed on the surface of ground $\mathrm{Cu}_{36} \mathrm{Zr}_{48} \mathrm{Ag}_{8} \mathrm{Al}_{8}$ powder (Figure $2 \mathrm{a}$ ). The $\mathrm{X}$-ray diffraction pattern of ground $\mathrm{Cu}_{36} \mathrm{Zr}_{48} \mathrm{Ag}_{8} \mathrm{Al}_{8}$ powder presents sharp Bragg peaks superimposed on the halo due to the presence of 
an amorphous phase (Figure 2b). Four crystalline phases were identified: $\mathrm{CuZr}$ (Fm-3m, 8.4 wt.\%), $\mathrm{CuZr}_{2}$ (I4/mmm, $\left.80.3 \mathrm{wt} . \%\right), \mathrm{Al}_{0.8} \mathrm{Ag}_{3.2}$ (Fm-3m, $\left.9.6 \mathrm{wt} . \%\right)$ and $\alpha$-Fe (Fm-3m, $\left.1.7 \mathrm{wt} . \%\right)$. The crystallite sizes are presented in Table 1. The unit cell of the CuZr phase is a $=0.3262 \mathrm{~nm}$ [26]. However, the Rietveld refinement shows that the unit cell of the CuZr phase is $a=0.4541 \mathrm{~nm}$, i.e., the crystal structure of this phase is distorted. This phenomenon occurs when $\mathrm{Cu}$ atoms are replaced by $\mathrm{Ag}$ and $\mathrm{Al}$ atoms, which have smaller atomic radii $\left(\mathrm{r}_{\mathrm{Al}}=0.143 \mathrm{~nm}, \mathrm{r}_{\mathrm{Ag}}=0.144 \mathrm{~nm}\right)$ compared to $\mathrm{Cu}\left(\mathrm{r}_{\mathrm{Cu}}=0.128 \mathrm{~nm}\right)$. This phase is hereinafter referred to as the $\mathrm{CuZr}(\mathrm{Ag}, \mathrm{Al})$ phase based on the $\mathrm{XRD}$ results. The "X-ray amorphous structure" content is $11.2 \mathrm{wt}$. \%. Observing the amorphous halo, the maximum position of the halo is $0.2182 \mathrm{~nm}$, which reflects the most frequent distances between atoms [27]. Figure 2c shows the thermal properties of $\mathrm{Cu}_{36} \mathrm{Zr}_{48} \mathrm{Ag}_{8} \mathrm{Al}_{8}$ amorphous-nanocrystalline powder. The glass temperature $\left(\mathrm{T}_{\mathrm{g}}\right.$ ) is $414{ }^{\circ} \mathrm{C}$, and the onset of crystallization $\left(\mathrm{T}_{\mathrm{x}}\right)$ is $494{ }^{\circ} \mathrm{C}$. The mode of the $\mathrm{Cu}_{36} \mathrm{Zr}_{48} \mathrm{Ag}_{8} \mathrm{Al}_{8}$ particle size distribution by LPSA is $21.3 \mu \mathrm{m}$ (Figure $2 \mathrm{~d}$ ). It is noteworthy that a small fraction of larger particles can be detected.

The amorphous content of raw $\mathrm{Cu}_{36} \mathrm{Zr}_{48} \mathrm{Ag}_{8} \mathrm{Al}_{8}$ alloy is characterized by two halos in the XRD pattern, which indicates the existence of two short-range orders in the amorphous phase. The first peak position of the amorphous halo is $0.22781 \mathrm{~nm}$, and the second peak position is $0.13896 \mathrm{~nm}$. The first short-range order is probably enriched in $\mathrm{Zr}$, while the second one is enriched in $\mathrm{Cu}$. Both the short-range orders contain $\mathrm{Ag}$ and $\mathrm{Al}$ atoms, too.
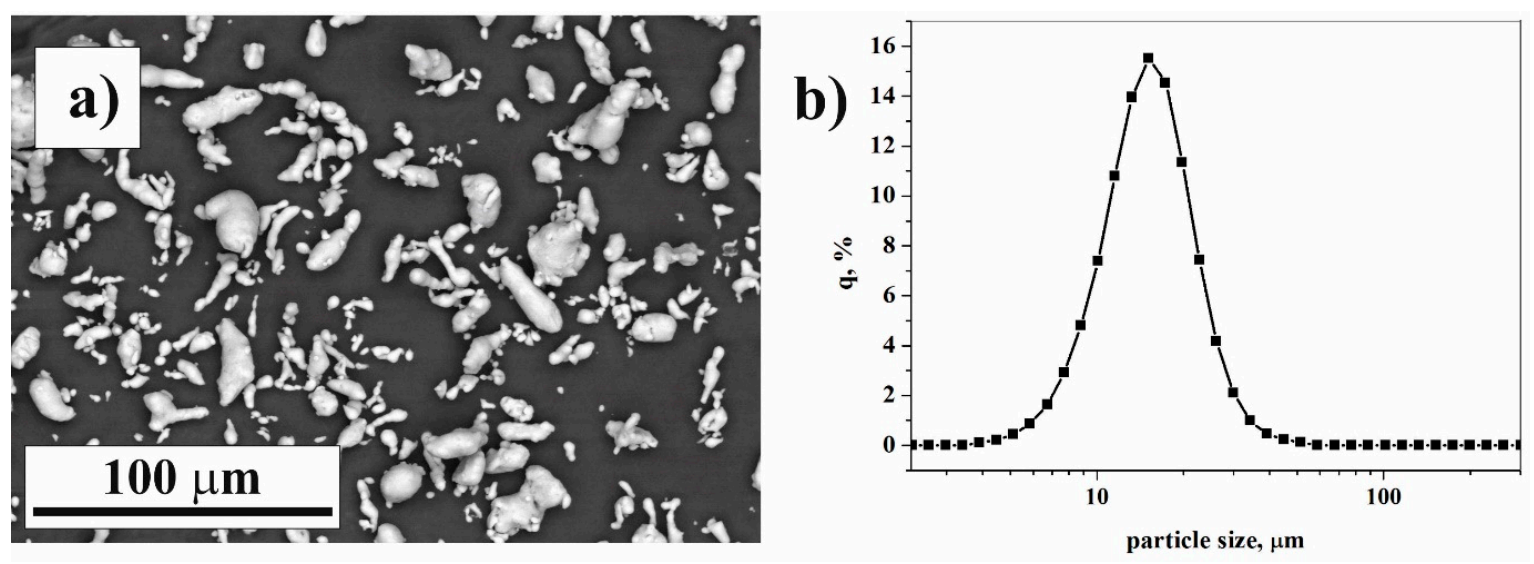

Figure 1. Scanning electron microscopic (SEM) image (a) and particle size distribution of the $\mathrm{Al}$ powder (b). 

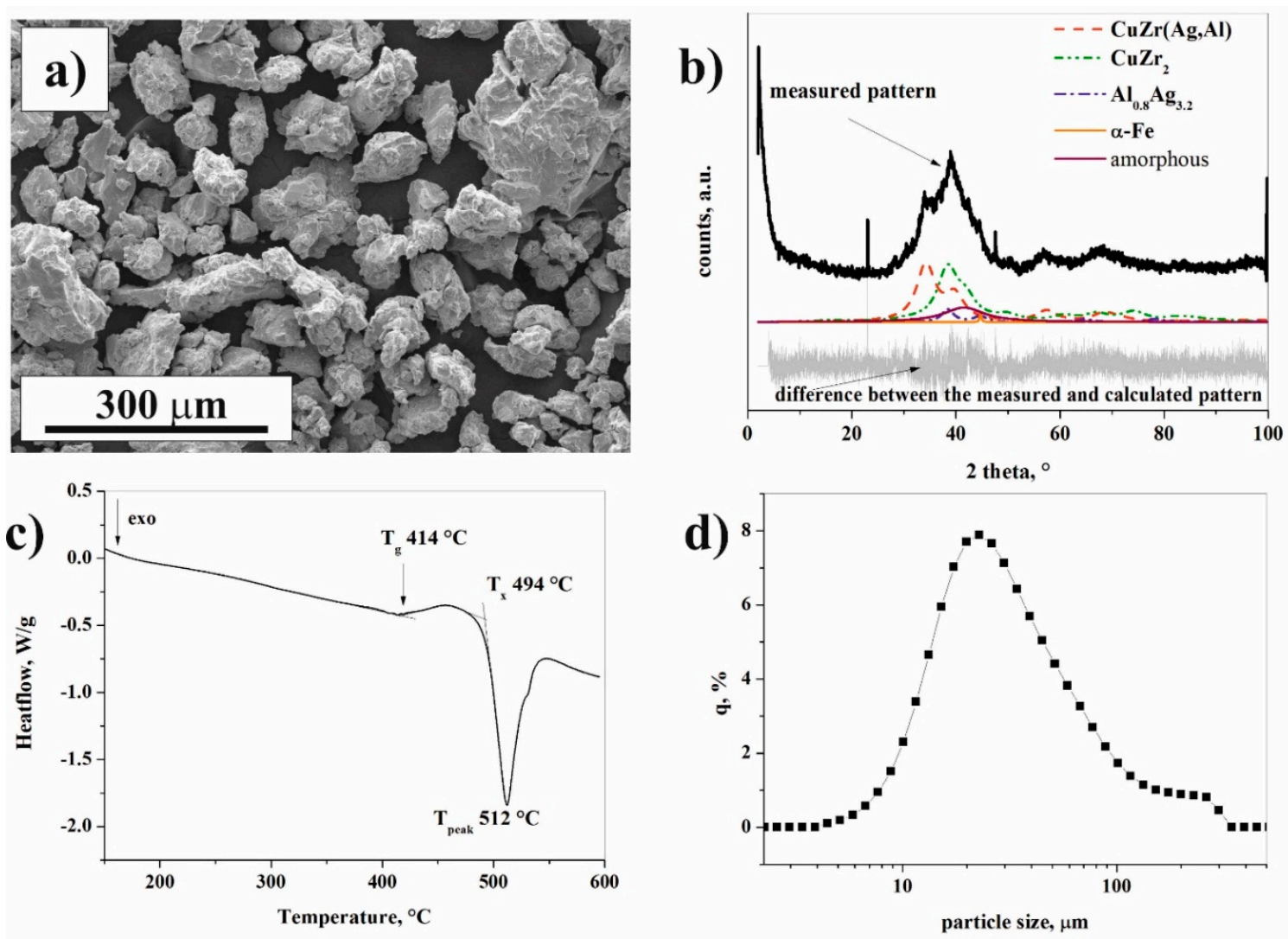

Figure 2. Scanning electron microscopic (SEM) images (a), XRD pattern (b), DSC thermogram (c), and particle size distribution (d) of the $\mathrm{Cu}_{36} \mathrm{Zr}_{48} \mathrm{Ag}_{8 \mathrm{Al}}$ powder.

Table 1. Features of the amorphous phase and the crystallites based on the XRD of raw and milled powder.

\begin{tabular}{|c|c|c|c|c|c|c|c|c|c|}
\hline \multirow{2}{*}{ Phase } & \multirow{2}{*}{ Milling Time, $\mathrm{h}$} & \multicolumn{7}{|c|}{ Without Ethanol } & \multirow{2}{*}{$\begin{array}{c}\begin{array}{c}\text { With } \\
\text { Ethanol }\end{array} \\
30\end{array}$} \\
\hline & & 0 & 5 & 10 & 15 & 20 & 25 & 30 & \\
\hline \multirow{2}{*}{$\begin{array}{c}\text { Al } \\
\text { Fm_3m }\end{array}$} & crystallite size, $\mathrm{nm}$ & 494-776 & 188-296 & $50-79$ & 70-110 & $55-86$ & $57-90$ & $72-113$ & $29-46$ \\
\hline & wt. \% Rietveld & 90.00 & 89.43 & 86.13 & 82.24 & 85.77 & 84.46 & 83.84 & 87.68 \\
\hline \multirow{2}{*}{$\begin{array}{c}\mathrm{CuZr}_{2} \\
\mathrm{I} 4 / \mathrm{mmm}\end{array}$} & crystallite size, $\mathrm{nm}$ & $1.3-2.0$ & $1.27-2.0$ & $1.27-2.0$ & $1.27-2.0$ & $1.27-2.0$ & $1.27-2.0$ & $1.27-2.0$ & $31-56$ \\
\hline & wt. \% Rietveld & 7.066 & 6.50 & 6.59 & 8.61 & 6.73 & 6.86 & 7.46 & 0.28 \\
\hline \multirow{2}{*}{$\begin{array}{c}\mathrm{CuZr}(\mathbf{A g}, \mathbf{A l}) \\
\text { Fm_3m }\end{array}$} & crystallite size, $\mathrm{nm}$ & $1-2.21$ & $1.27-2.0$ & $1.27-2.0$ & $1.27-2.0$ & $1.27-2.0$ & $1.27-2.0$ & $1.27-2.0$ & $3-5$ \\
\hline & wt. \% Rietveld & 0.739 & 0.95 & 1.51 & 1.92 & 1.73 & 1.97 & 2.10 & 0.35 \\
\hline \multirow{2}{*}{$\begin{array}{c}\mathrm{CuZr} \\
\mathrm{Fm} \_3 \mathrm{~m}\end{array}$} & crystallite size, nm & - & - & - & - & - & - & - & $3-5$ \\
\hline & wt. \% Rietveld & - & - & - & - & - & - & - & 0.34 \\
\hline \multirow{2}{*}{$\begin{array}{c}\mathbf{A l}_{0.8} \mathbf{A g}_{3.2} \\
\mathrm{Fm} \_3 \mathrm{~m}\end{array}$} & crystallite size, $\mathrm{nm}$ & $2.0-3.3$ & $42-66$ & $5.9-9.3$ & $9.1-14.3$ & $5.4-8.4$ & $4.6-7.3$ & $6.7-10.5$ & $6-10$ \\
\hline & wt. \% Rietveld & 0.845 & 2.11 & 4.64 & 5.17 & 4.48 & 5.12 & 4.93 & 0.35 \\
\hline \multirow{2}{*}{$\begin{array}{l}\text {-Iron } \\
\text { Im_3m }\end{array}$} & crystallite size, nm & $20.6-32.4$ & $3.6-5.8$ & $7.6-12.1$ & $5.4-8.4$ & $6.7-10.5$ & $7.9-12.5$ & $6.9-10.9$ & - \\
\hline & wt. \% Rietveld & 0.150 & 1.02 & 1.13 & 2.07 & 1.29 & 1.59 & 1.67 & - \\
\hline amorphous & wt. \% Rietveld & 0.12 & 0 & 0 & 0 & 0 & 0 & 0 & 11.00 \\
\hline
\end{tabular}

\subsection{Composite Material of A1 Experiment (without Ethanol)}

\subsubsection{Particle Morphology and Size Distribution}

Figure 3 a shows the morphological variation of Al-CuZrAgAl composition obtained by SEM after $5 \mathrm{~h}, 10 \mathrm{~h}, 15 \mathrm{~h}, 20 \mathrm{~h}, 25 \mathrm{~h}$, and $30 \mathrm{~h}$ milling time, respectively. The darker particles in all the backscattered 
SEM images correspond to $\mathrm{Al}$ particles, whereas the brighter phase indicates the $\mathrm{Cu}_{36} \mathrm{Zr}_{48} \mathrm{Ag}_{8} \mathrm{Al}_{8}$ particles. At the 5-hour milling stage, the ductile Al powder particles are flattened, plastically deformed and fractured due to the collision of the grinding balls. The $\mathrm{Cu}_{36} \mathrm{Zr}_{48} \mathrm{Ag}_{8} \mathrm{Al}_{8}$ particles are fragmented and these particles are separated from each other and from the Al particles (Figure 3a). The particle size distribution is symmetric (Figure 3b). The mode of the composite particle is $12.3 \mu \mathrm{m}$. The $\alpha$-Fe content is considered contamination of the milling process coming from the milling media. Based on the XEDS-SEM mapping (Figure 4), the $\alpha$-Fe can be detected on the surface of $\mathrm{Cu}_{36} \mathrm{Zr}_{48} \mathrm{Ag}_{8} \mathrm{Al}_{8}$ particles already after $5 \mathrm{~h}$ milling time.

a)
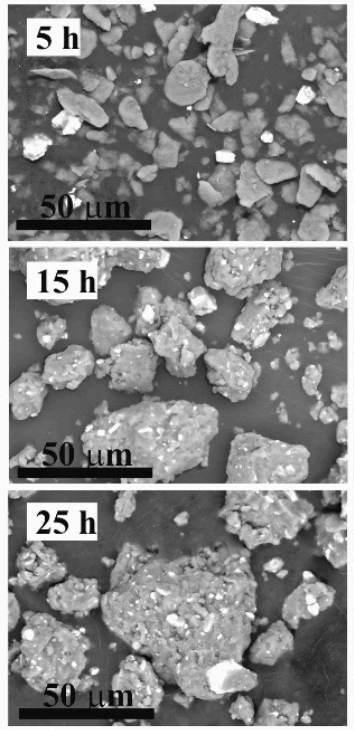
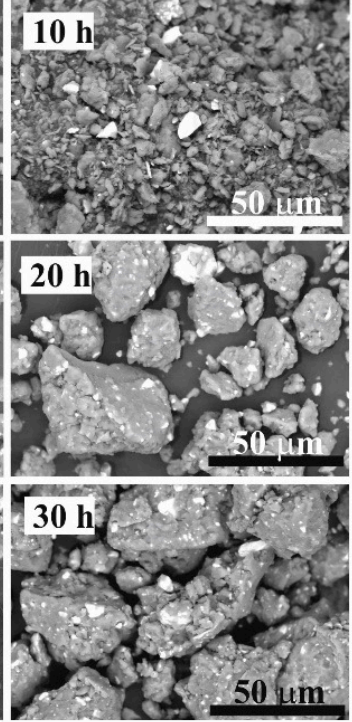
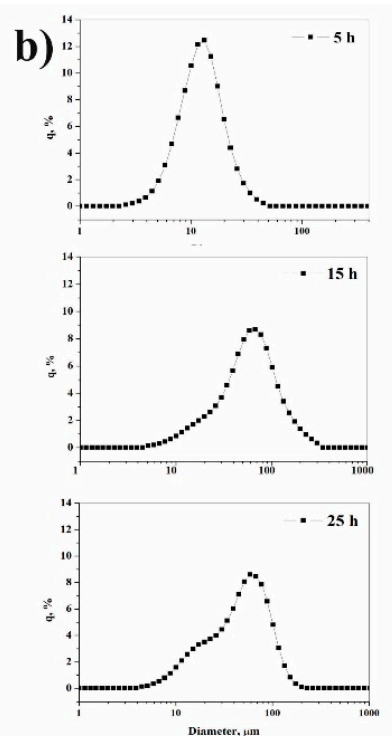

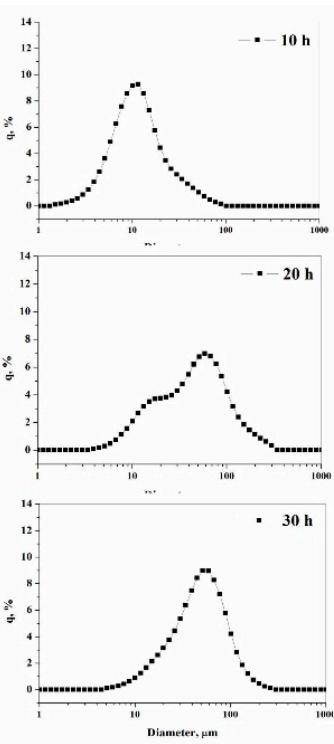

Figure 3. Backscattered SEM images (a) and particle size distribution (b) of mixed powders milled for different periods of time.
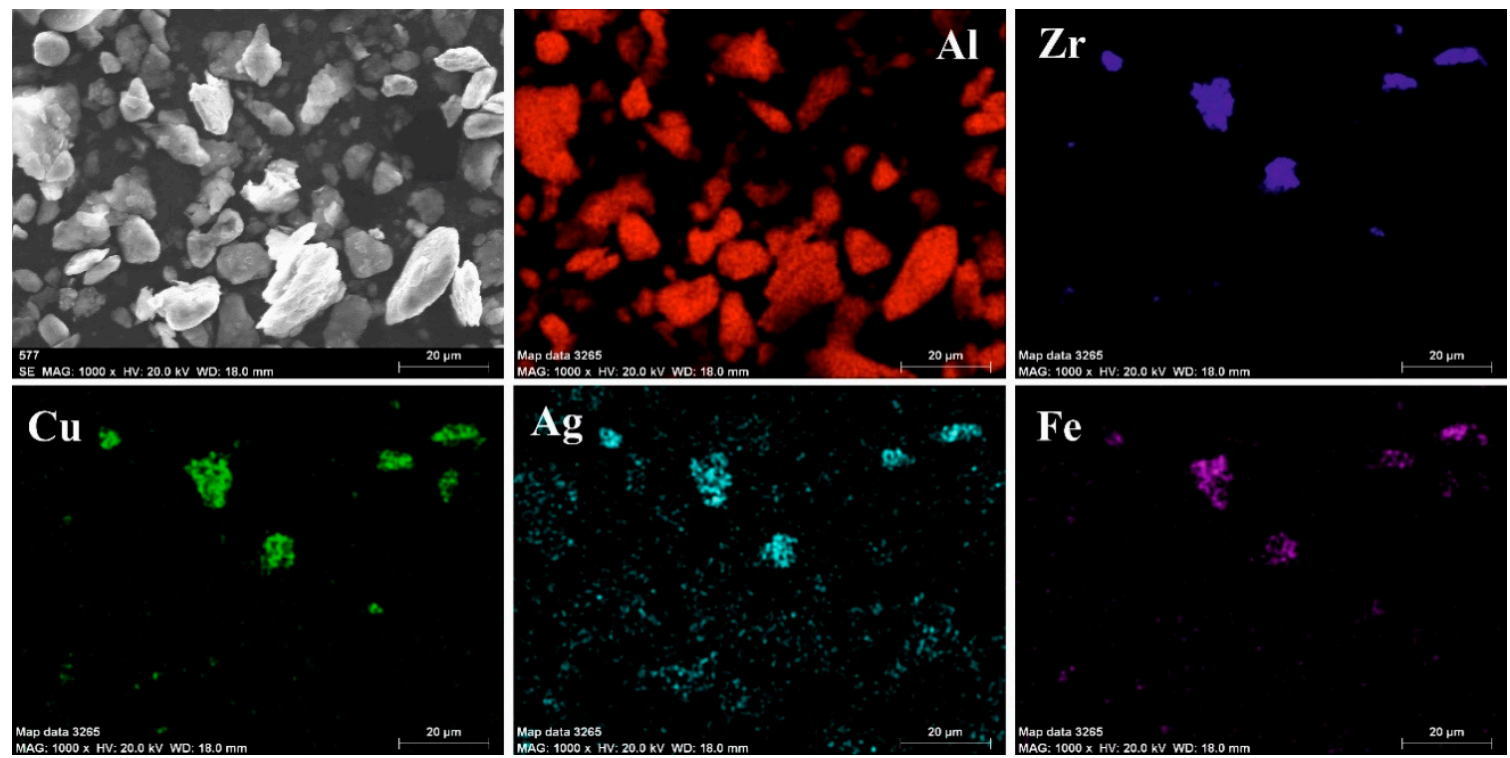

Figure 4. SEM micrograph and characteristic compositional XEDS-SEM mapping of $5 \mathrm{~h}$ milled powder.

After $10 \mathrm{~h}$ milling time, the fragmentation of the $\mathrm{Al}$ particles is remarkable (Figure $3 \mathrm{a}$ ). It is quite clear from all SEM images that besides the fragmentation, the agglomeration of the Al particles takes place. The particle size distribution confirms this process; larger particles appear (Figure $3 b$ ), and the distribution curve is no longer symmetrical. The bigger $\mathrm{Cu}_{36} \mathrm{Zr}_{48} \mathrm{Ag}_{8} \mathrm{Al}_{8}$ particles are not yet generally connected to the $\mathrm{Al}$ particles. 
The most significant change is observed between 10 and $15 \mathrm{~h}$ milling time. This could be attributed to the tendency that cold welding between the $\mathrm{Al}-\mathrm{Al}$ and $\mathrm{Al}-\mathrm{Cu}_{36} \mathrm{Zr}_{48} \mathrm{Ag}_{8} \mathrm{Al}_{8}$ particles dominates their fracture. After $15 \mathrm{~h}$ of milling, the mode of composite powder has increased to $63.0 \mu \mathrm{m}$. $\mathrm{Al}$ particles are stuck to and surround the reinforcing particles (Figure 3a). Further milling results in severe plastic deformation of clusters and reduction of the particle size. With the milling time extended, composite powders are broken up and cold welding repeatedly takes place. The volume distribution by LPSA shows that bimodal distribution is formed after 20 and $25 \mathrm{~h}$ of milling time (Figure $3 \mathrm{~b}$ ). The higher mode of particles decreases to $55.1 \mu \mathrm{m}$ and $55.3 \mu \mathrm{m}$ after 20 and $25 \mathrm{~h}$ milling time, respectively. The smaller mode of particles is $22.8 \mu \mathrm{m}$ in both cases. This bimodal character disappears after further milling. The mode of particles decreases to $48.5 \mu \mathrm{m}$ after $30 \mathrm{~h}$ milling time (Figure 3b). The cross-sectional SEM micrograph of the composite particles shows good bonding at the matrix/particle interface (Figure 5). Many reinforcing particles are trapped in the cold-welded $\mathrm{Al}$ particles, which is the matrix. The reinforcing particles are fractured into several pieces owing to the large shear deformation. Some broken pieces of reinforcing particles can be seen in the inside composite particle (Figure $5 c, d$ ) or/and on the surface of the composite particles (Figure $5 c$ ).
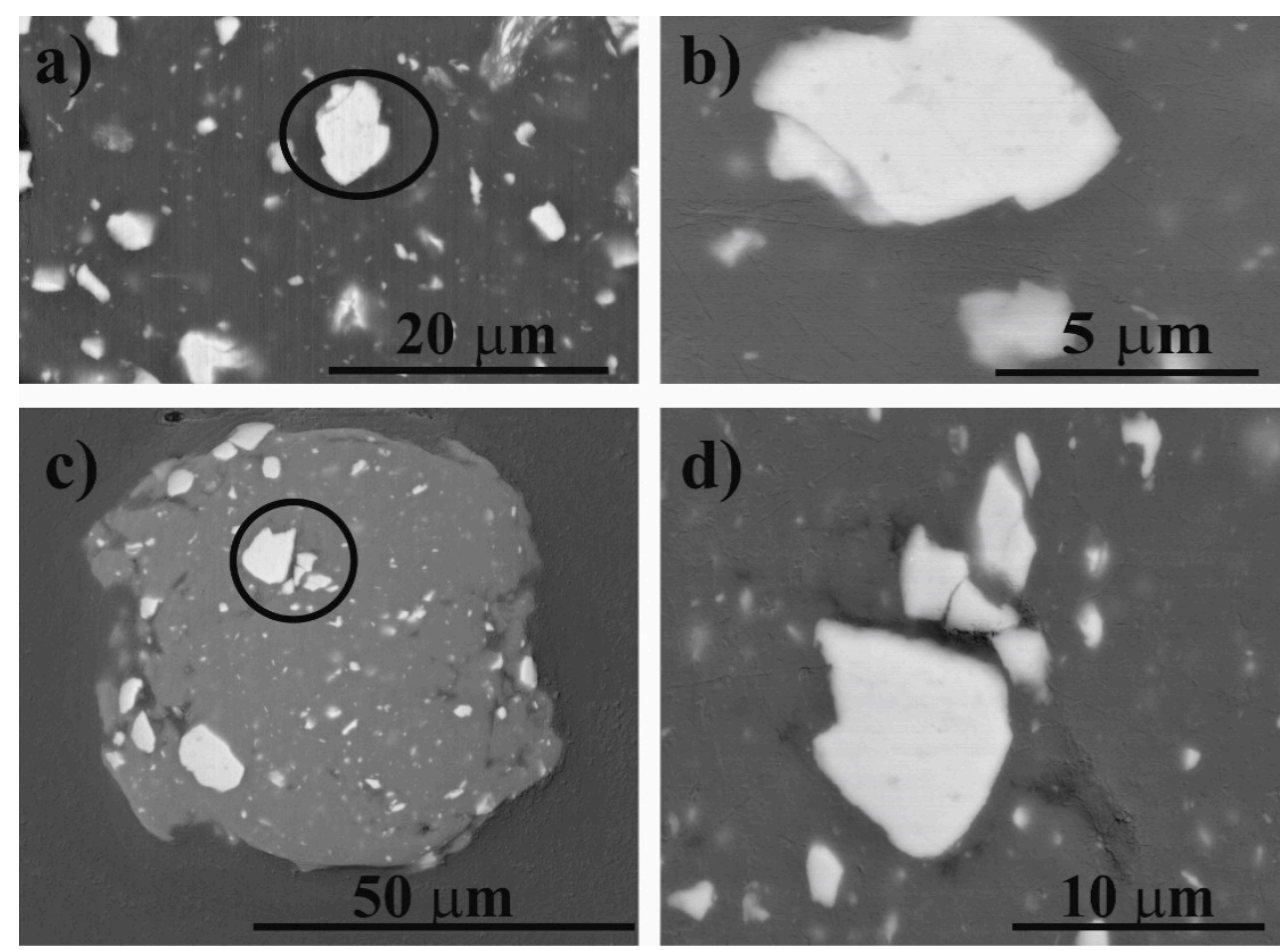

Figure 5. Cross-sectional backscattered SEM images of composite particles after $15 \mathrm{~h}(\mathbf{a}, \mathbf{b})$ and $25 \mathrm{~h}$ $(\mathbf{c}, \mathbf{d})$ of milling time. Representative images showing particle/matrix interface $(\mathbf{b}, \mathbf{d})$.

Summarizing the morphology and particle size analysis, we can conclude that in the initial stage ( $5 \mathrm{~h}$ milling time), the ductile $\mathrm{Al}$ phase is flattened, and the brittle phase is fragmented. Further milling leads to the formation of new surfaces between the fractured and deformed powder particles, which is due to the force of impact. These new surfaces cold weld and larger particles form due to the large surface area and the lack of surfactant to prevent direct contact between them. Then the $\mathrm{Al}-\mathrm{Al}$ and Al-reinforcing phases would stick together, which causes the average powder size to increase after $15 \mathrm{~h}$ of milling (Figure 6). 


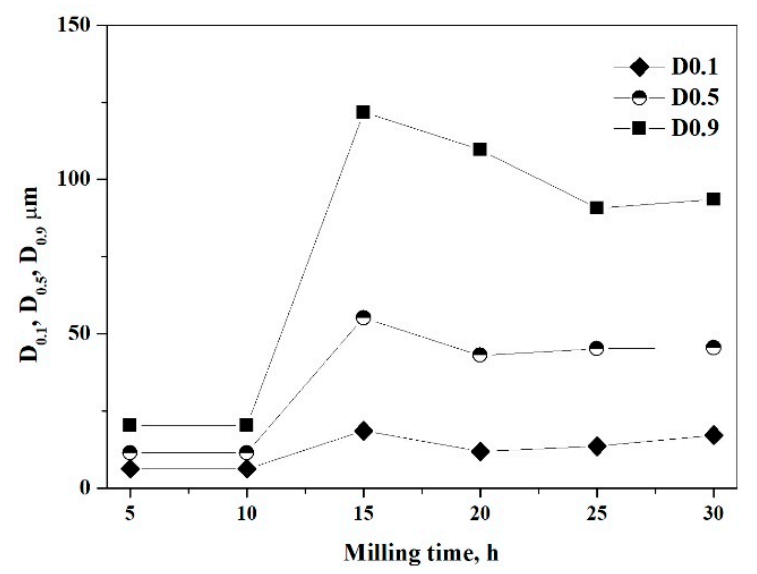

Figure 6. Particle sizes $\mathrm{D}_{0.1}, \mathrm{D}_{0.5}$, and $\mathrm{D}_{0.9}$ of the composite as a function of the milling time $\left(\mathrm{D}_{0.1}, \mathrm{D}_{0.5}\right.$, and $\mathrm{D}_{0.9}$ diameters correspond to 10,50 , and $90 \%$ fineness of the particle size volume distribution, respectively).

With the milling time extended, the ductile Al particles become harder due to the cold work of the balls. The composite powder is repeatedly broken and cold-welded. Between 15 and $20 \mathrm{~h}$ of milling time, fracturing is the determining factor that causes reduction in the particle size. Observing the median of the particle size distribution, a steady state is reached after $25 \mathrm{~h}$ milling time.

\subsubsection{Phases and Grain Size Analyses using the XRD Method}

Figure 7a shows the XRD patterns of Al-composites with different milling times and of the initial powders. The pattern of composite powder after ball milling for $5 \mathrm{~h}$ displays sharp $\mathrm{Al}$ peaks with other peaks but without an amorphous halo. During the milling process, crystalline defects (dislocations and stacking faults) form due to the repeated impact and shear forces of the milling media $[26,28]$. Owing to the input energy of the milling process, sub-grains, and high-angle grain boundaries are created in the Al matrix. Significant broadening and height reduction in the intensity of the Al peaks are observed with milling time owing to grain size refinement, lattice strain (Figure 7b). The increase in the width of XRD peaks clearly indicates the grain size reduction and increase in the lattice strain (Table 1).
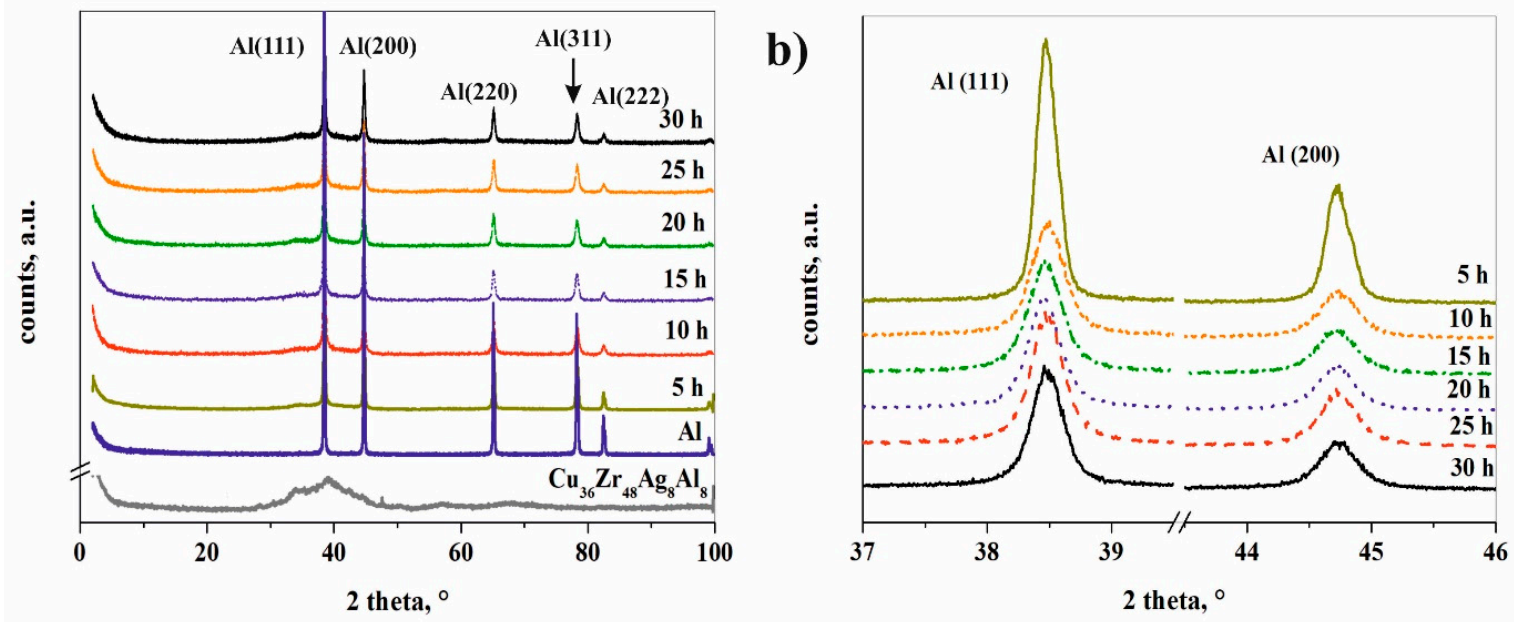

Figure 7. XRD patterns of the composite powders and initial powders (a) and intensity reduction of $\mathrm{Al}$ (111) and (200) peaks at different time intervals (b).

It is well known in the literature that oxygen has an essential effect on the glass forming ability $[29,30]$. Furthermore, the interface between an amorphous particle and its oxide layer can act as a heterogeneous nucleation site for crystallization during thermal annealing of the amorphous 
particle [31]. A thin oxide layer exists on the surface of both initial powders. If $\mathrm{CuZr}(\mathrm{Ag}, \mathrm{Al}), \mathrm{CuZr} \mathrm{r}_{2}$ or amorphous phases are located on a particle surface, the composition of the layer is $\mathrm{ZrO}_{2}$ [32]. In the case of the $\mathrm{Al}$ and $\mathrm{Al}_{0.8} \mathrm{Ag}_{3.2}$ phase, the oxide layer is $\mathrm{Al}_{2} \mathrm{O}_{3}$. Under the milling process of the reinforcing particles $\mathrm{Cu}, \mathrm{Al}, \mathrm{Ag}$ and $\mathrm{Zr}$ atoms become surface atoms. Of course, these atoms can also be oxidized by the atmosphere. Despite using argon gas during the milling process, oxygen is found in the milling material, and one can only minimize further oxidation.

According to the Rietveld refinement, the initial amorphous-nanocrystalline $\mathrm{Cu}_{36} \mathrm{Zr}_{48} \mathrm{Ag}_{8} \mathrm{Al}_{8}$ alloy transforms into nanocrystalline phases after $5 \mathrm{~h}$ milling time (Table 1). It can be established that the thin oxide layer has such a strong effect that it prevents the amorphization despite the high amount of input energy during the milling process. Three phases crystallize from the amorphous-nanocrystalline alloy due to the input energy from milling: $\mathrm{Al}_{0.8} \mathrm{Ag}_{3.2}, \mathrm{CuZr}_{2}$, and $\mathrm{CuZr}(\mathrm{Ag}, \mathrm{Al}$ ) (Figure 8 and Table 1). J. Cui et al. [33] investigated the crystallization of $\mathrm{Cu}_{36} \mathrm{Zr}_{48} \mathrm{Ag}_{8} \mathrm{Al}_{8}$ alloy in non-isothermal and isothermal modes. Under non-isothermal conditions, the $\mathrm{CuZr}$ phase and the AlAg phase crystallize, while under isothermal conditions the $\mathrm{CuZr}, \mathrm{AlAg}$ and $\mathrm{AgZr}$ phases crystallize [33]. It is worth noting that $\mathrm{CuZr}_{2}, \mathrm{AlCu}_{2} \mathrm{Zr}, \mathrm{AgZr}_{2}$, and unknown phases were identified by Wei Zhang et al. [34] in water-quenched $\mathrm{Cu}_{36} \mathrm{Zr}_{48} \mathrm{Ag}_{8} \mathrm{Al}_{8}$ alloy with a $25 \mathrm{~mm}$ diameter. It can be stated that different phases crystallized partly due to the milling process rather than the solidifying process.

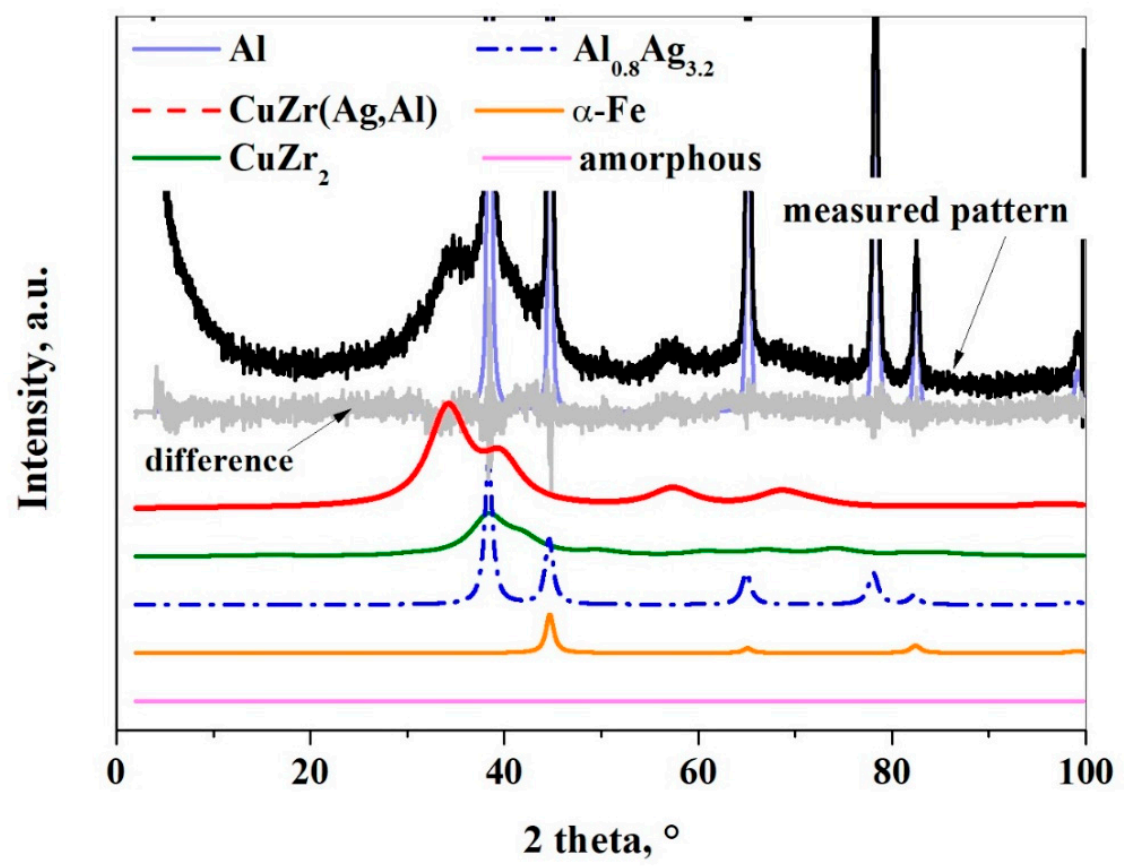

Figure 8. XRD pattern of the composite powder after $30 \mathrm{~h}$ milling time without using ethanol.

The weight fraction of the $\mathrm{CuZr}_{2}$ phase is approximately constant during the whole milling process (Figure 10a). On the contrary, the amount of the aluminum-containing phases strongly increases; the weight fractions of the $\mathrm{Al}_{0.8} \mathrm{Ag}_{3.2}$ and $\mathrm{CuZr}(\mathrm{Ag}, \mathrm{Al})$ phases increase by more than 5 and 2 times, respectively, at the end of milling process (Table 1). The impurity $\alpha$-Fe content increases with the milling time up to $15 \mathrm{~h}$ (Figure 9). The maximal content that evolved in our experiments was $2.1 \mathrm{wt}$. \% according to XRD.

The crystallite size of the Al matrix and other phases in the mechanically milled powders can be calculated by the Rietveld refinement. After $5 \mathrm{~h}$ of milling time, the crystallite size of $\mathrm{CuZr}_{2}$ and $\mathrm{CuZr}(\mathrm{Ag}, \mathrm{Al})$ is $1.27-2.0 \mathrm{~nm}$ and is constant during further milling (Table 1). On the contrary, the crystallite size of Al powder decreases drastically from 494-776 nm to $50-79 \mathrm{~nm}$ within $10 \mathrm{~h}$ of milling. Between 15 and $30 \mathrm{~h}$ of milling time, the change of crystallite size is not significant. 
The crystallite size of the $\mathrm{Al}_{0.8} \mathrm{Ag}_{3.2}$ phase increases after $5 \mathrm{~h}$ milling time and decreases to the near initial size after $10 \mathrm{~h}$ of milling. With further milling, the crystallite size remains approximately constant.

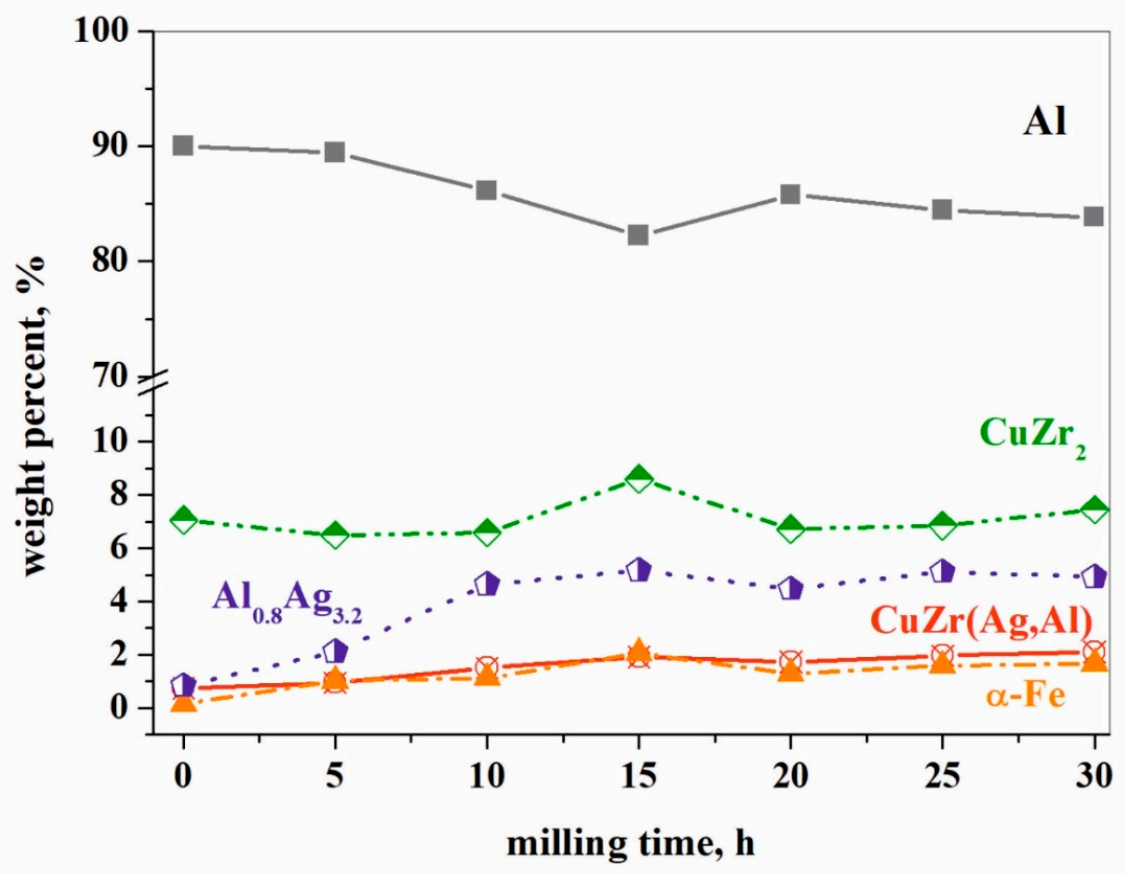

Figure 9. Effect of milling time on the weight fraction of different phases.

\subsection{Composite Material of the A2 Experiment (with Ethanol)}

In the case of the A2 experiment, the grinding bowl is not opened during $30 \mathrm{~h}$ of milling. Before milling the atmosphere is filled with argon and some ethanol as a process control agent (PCA) is added. With every opening, the air inevitably enters the grinding bowl. It is known that ethanol adsorbs on the powder surface and reduces consequently the surface tension of the solid material [28]. The molecule size of ethanol is $0.44 \mathrm{~nm}$. Ethanol is a good wetting agent for all metallic materials. Ethanol fills first the places where the surface tension is greater, that is, the gaps and the pores of metallic particles. Later it covers the surface of particles where the surface tension is smaller. Copper oxide removal can be achieved by ethanol at temperatures as low as $130^{\circ} \mathrm{C}$ [35]. The reduction of silver oxide by ethanol can also take place (silver mirror test).

One can observe a significant difference between wet milled and dry milled samples. The presence of ethanol diminishes the cold welding between $\mathrm{Al}-\mathrm{Al}$ particles and Al-reinforcing particles. SEM micrograph of the composite powder reveals that many of the $\mathrm{Cu}_{36} \mathrm{Zr}_{48} \mathrm{Ag}_{8} \mathrm{Al}_{8}$ alloy particles are not cold-welded to Al particles (Figure 10a). Due to the intensive impacts of the balls-as a result of collision-the ethanol and oxide layers break. However, not only the thin layer breaks but the particles also. New active surfaces develop so cold welding between the particles can take place. Figure $10 \mathrm{~b}$ shows that the small $\mathrm{Cu}_{36} \mathrm{Zr}_{48} \mathrm{Ag}_{8} \mathrm{Al}_{8}$ alloy particles are cold-welded to $\mathrm{Al}$ particles. 

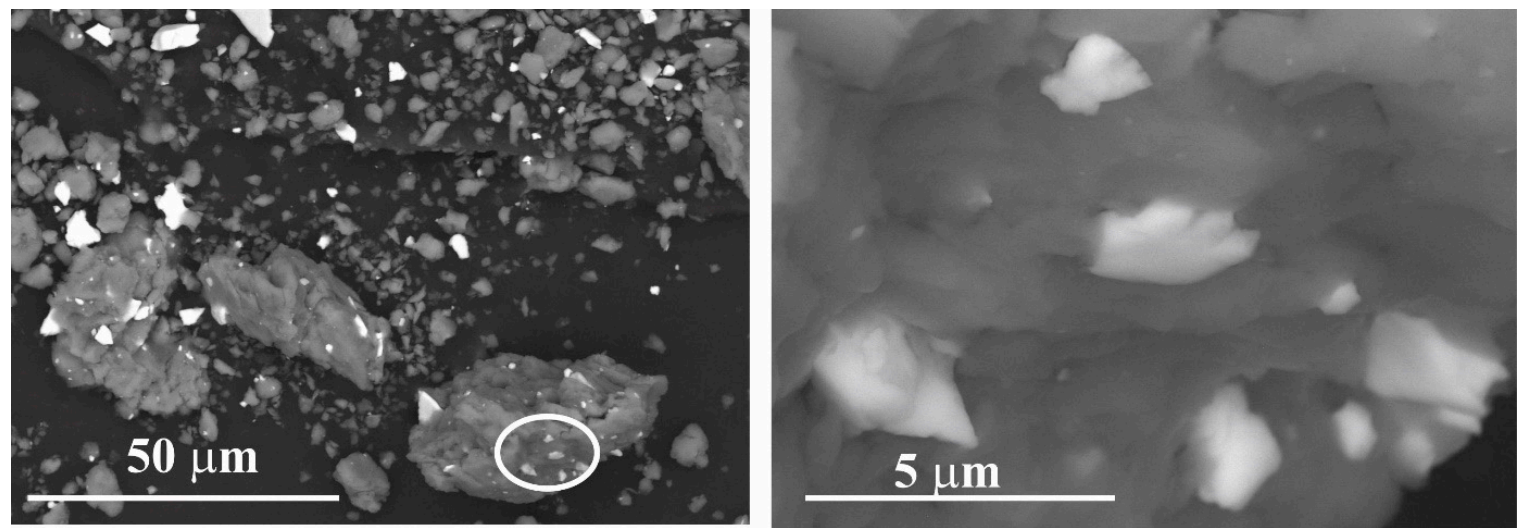

Figure 10. Backscattered SEM images of the composite material after $30 \mathrm{~h}$ milling time using ethanol as PCA (a) and magnified image of the area marked by the circle (b).

The initial phases remain, except the $\alpha$-Fe contamination based on the XRD analysis (Figure 11). However, their weight fraction reduces greatly except for the Al phase. The crystallite sizes are much larger than in the first experiment owing to the ethanol layer. Two different $\mathrm{CuZr}$ phases were detected by XRD. The unit cell of the initial $\mathrm{CuZr}(\mathrm{Ag}, \mathrm{Al})$ phase has changed from $0.4541 \mathrm{~nm}$ to 0.4559 . It can be explained that some $\mathrm{Al}$ atoms $\left(\mathrm{r}_{\mathrm{Al}}=0.1432 \mathrm{~nm}\right)$ replace $\mathrm{Cu}$ atoms $\left(\mathrm{r}_{\mathrm{Cu}}=0.1278 \mathrm{~nm}\right)$. The unit cell of the new CuZr phase is $0.4308 \mathrm{~nm}$, which is closer than the equivalent unit cell of the $\mathrm{CuZr}$ phase $(\mathrm{a}=0.3262 \mathrm{~nm})$. The $\alpha$-Fe contamination phase is not detectable after $30 \mathrm{~h}$ milling time.

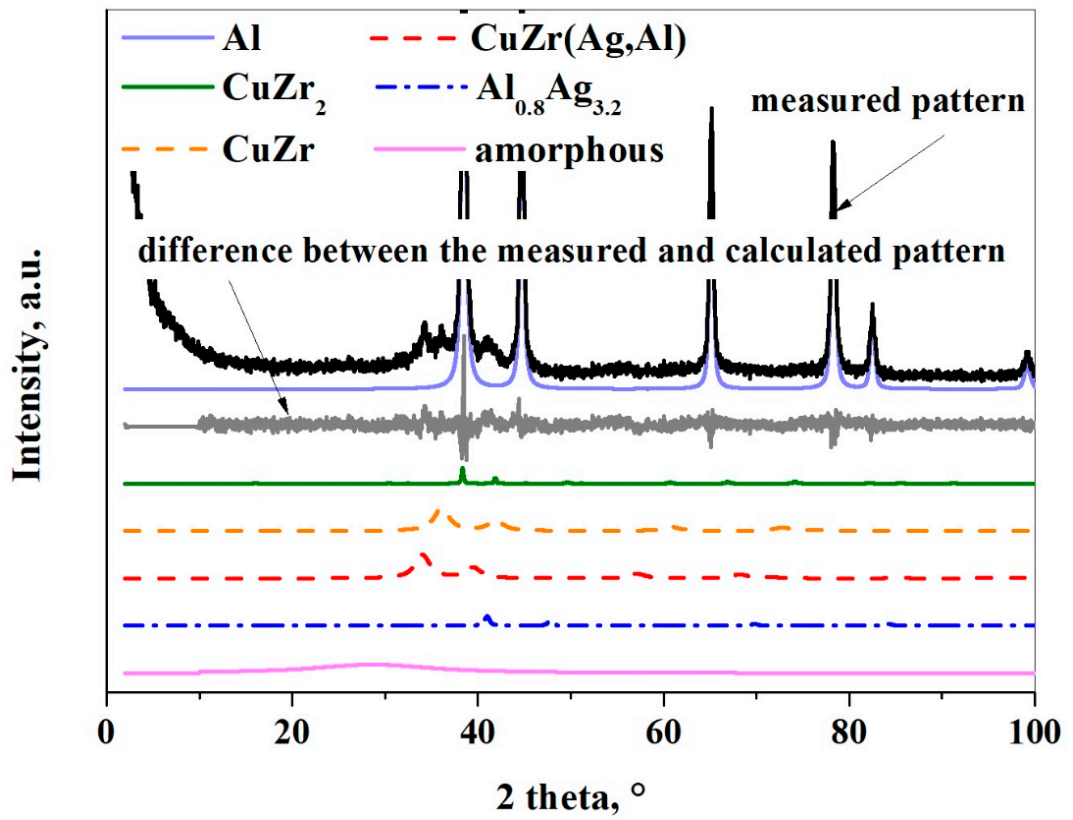

Figure 11. XRD pattern of the composite powder after $30 \mathrm{~h}$ of milling with using ethanol.

Modeling amorphous components, or "short-range ordered phases", by the peak fitted to the halo (hump) method was useful and allowed us to extract information on the composition of the amorphous phases and the size range of domains with different compositions. The results show that the presence of PCA is necessary for the formation of an amorphous phase because the ' $\mathrm{X}$-ray amorphous' fraction increases by more than nine times after $30 \mathrm{~h}$ of milling (Table 1). The maximum position of the amorphous halo has increased from $0.2182 \mathrm{~nm}$ to $0.3203 \mathrm{~nm}$ after $30 \mathrm{~h}$ milling time. The maximum position of the halo reflects the most frequent distances between atoms, so the amorphous structure contains larger atoms than in the case of the raw material. In this system, the larger atom is $\mathrm{Zr}$ with 
a $0.1603 \mathrm{~nm}$ atomic radius, while $\mathrm{Ag}, \mathrm{Fe}$, and $\mathrm{Cu}$ are smaller atoms having atomic radii of 0.1445 , 0.1241 , and $0.1278 \mathrm{~nm}$, respectively. The amount of the initial $\mathrm{Zr}$ containing crystalline phases as $\mathrm{CuZr}_{2}$, $\mathrm{CuZr}(\mathrm{Ag}, \mathrm{Al})$ decreased drastically, so the amorphous phase is enriched by zirconium.

The thermal analysis of composite powder confirms the presence of the amorphous phase. The peak position of crystallization changes from $512{ }^{\circ} \mathrm{C}$ to $499.5^{\circ} \mathrm{C}$, which means that the composition of the amorphous phase has changed (Figure 12).

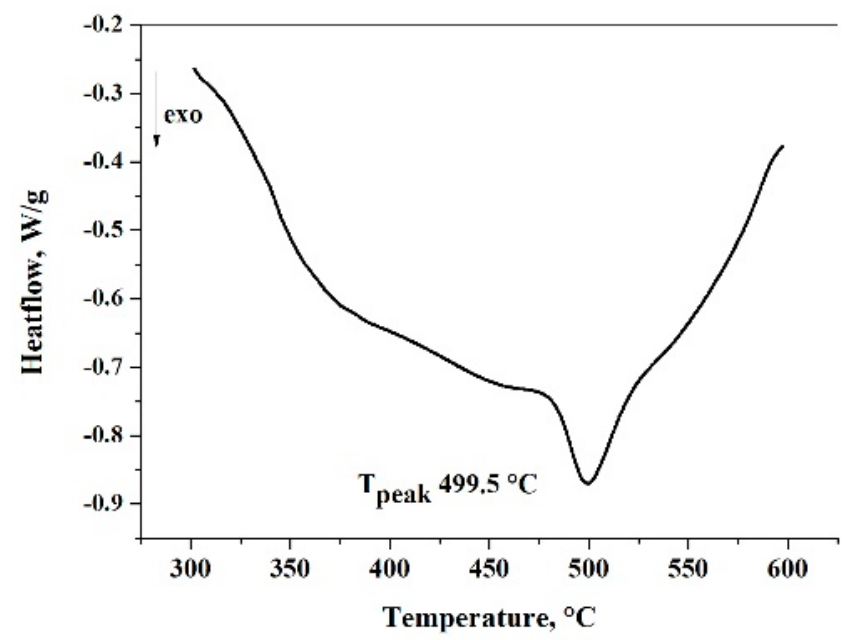

Figure 12. DSC curve from the composite powder after $30 \mathrm{~h}$ milling time using ethanol measured at a heating rate of $40 \mathrm{~K} / \mathrm{min}$.

It is known from the literature that organic PCAs decompose during milling $[22,23]$. Some authors reported that oxygen, carbon, and hydrogen interact with the milled powder. $\mathrm{Al}_{2} \mathrm{O}_{3}$ and $\mathrm{Al}_{4} \mathrm{C}_{3}$ phases were revealed as impurities in the structure of the material [36,37], but both phases were not detectable after $30 \mathrm{~h}$ milling time in the present study. In order to clarify the effect of ethanol during the milling process and knowing that ethanol has a reduction ability and that the input energy is very high during the ball milling process, the volatile substances in the milling bowl were analyzed by gas chromatography. A schematic of the milling process without and with ethanol is shown in Figure 13.

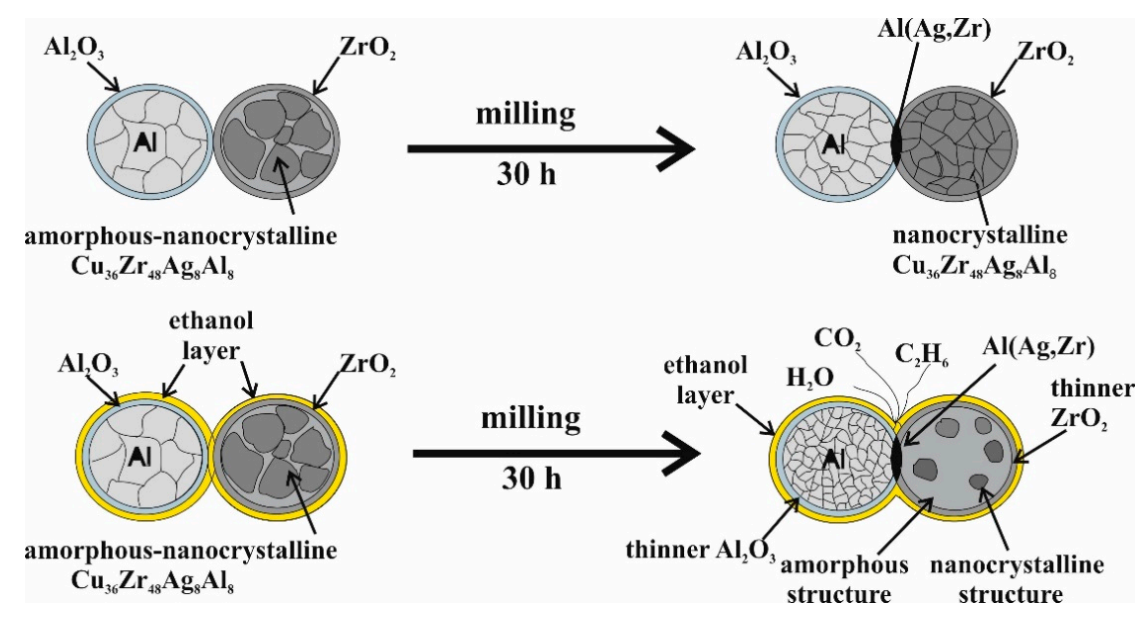

Figure 13. Schematic of the milling process without and with ethanol.

Figure 14a confirms that ethanol has decomposed to carbon dioxide, water, and ethane. It is explained by the involvement of oxygen from the oxide layer of the particles and of hydrogen dissolved in the alloy. The first step of the reaction could be the dehydration of ethanol (Equation (1)). At the same time, the hydrogenation of ethylene to ethane (Equation (2)) and the oxidation of ethanol (Equation (3)) 
takes place in the system. All the necessary conditions, such as high temperature and catalysts $\left(\mathrm{Al}_{2} \mathrm{O}_{3}\right.$ from the oxide layer and $\mathrm{Ni}$ from the balls and bowl) are provided in the course of milling. A small hydrogen content can be found in the amorphous-nanocrystalline $\mathrm{Cu}_{36} \mathrm{Zr}_{48} \mathrm{Ag}_{8} \mathrm{Al}_{8}$ alloy which can interact with ethylene when the particles break, and a new active layer develops.

$$
\begin{gathered}
\mathrm{C}_{2} \mathrm{H}_{5}-\mathrm{OH} \stackrel{\mathrm{t}^{\circ} \mathrm{C}, \mathrm{Al}_{2} \mathrm{O}_{3}}{\rightarrow} \mathrm{CH}_{2}=\mathrm{CH}_{2}+\mathrm{H}_{2} \mathrm{O} \\
\mathrm{CH}_{2}=\mathrm{CH}_{2}+\mathrm{H}_{2} \stackrel{\mathrm{t}^{\circ} \mathrm{C}, \mathrm{Ni}}{\rightarrow} \mathrm{CH}_{3}-\mathrm{CH}_{3} \\
\mathrm{C}_{2} \mathrm{H}_{5}-\mathrm{OH}+3 \mathrm{O}_{2} \stackrel{\mathrm{t}^{\circ} \mathrm{C}}{\rightarrow} 2 \mathrm{CO}_{2}+3 \mathrm{H}_{2} \mathrm{O}
\end{gathered}
$$

Figure $14 \mathrm{~b}$ confirms the presence of combustible gas by burning as soon as the grinding bowl is opened. The oxygen atoms for the oxidation of ethanol are obtained from the oxide layer of the surface of the aluminum and $\mathrm{Cu}_{36} \mathrm{Zr}_{48} \mathrm{Ag}_{8} \mathrm{Al}_{8}$ powder. As a result, ethanol decreases the oxygen content of the milling material, which helps develop the amorphous content. Comparing the high-energy ball milling without and with ethanol it can be established that ethanol not only reduces the surface tension, but the abovementioned (Equations (1)-(3)) mechanochemical processes promote the development of the amorphous-nanocrystalline structure.
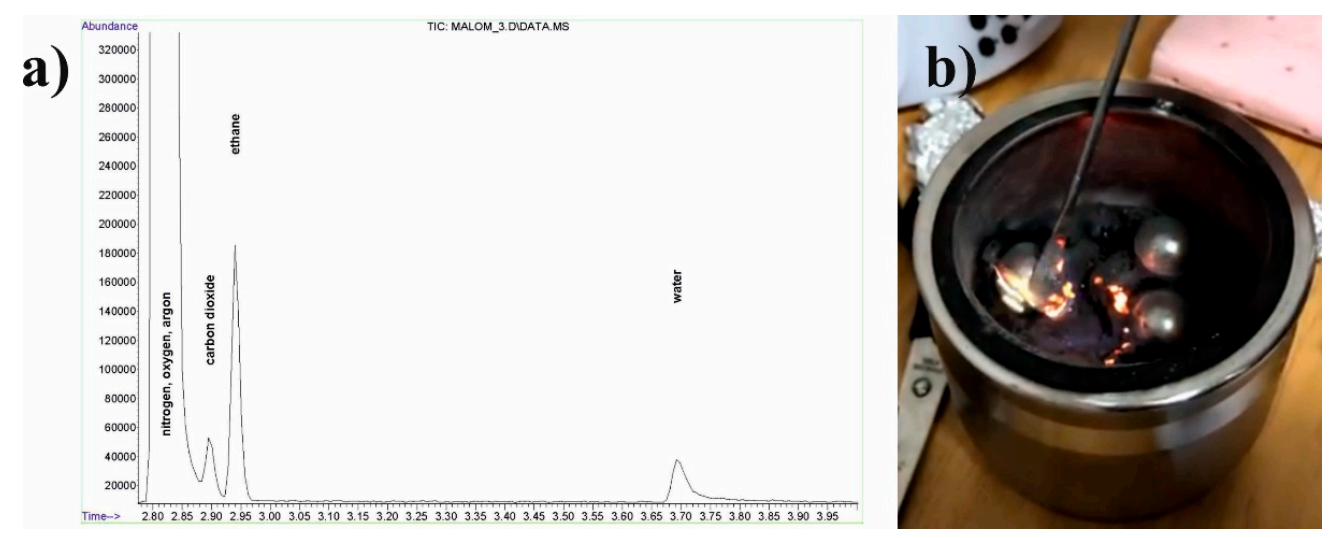

Figure 14. (a) Chromatogram of volatile substances in the milling bowl and (b) burning of ethane after $30 \mathrm{~h}$ milling time.

\section{Conclusions}

Pure $\mathrm{Al}$ and amorphous-nanocrystalline $\mathrm{Cu}_{36} \mathrm{Zr}_{48} \mathrm{Ag}_{8} \mathrm{Al}_{8}$ alloy powder were milled with and without ethanol by a high-energy mill for up to $30 \mathrm{~h}$. The main conclusions which can be drawn are as follows:

In the case of dry milling:

1. The amorphous phase disappears after $5 \mathrm{~h}$ milling time and does not develop until $30 \mathrm{~h}$ milling time. The thin oxide layer can act as a heterogeneous nucleation site for crystallization.

2. The repetitive impact of the balls can create a strong bond between the $\mathrm{Al}-\mathrm{Al}$ particles and Al-reinforcing particles after $15 \mathrm{~h}$ milling time.

3. The most significant change in the crystallite size takes place between 0 and $15 \mathrm{~h}$ of milling time.

Milling the Al powder for the composite matrix leads to a considerable refinement; the grain size of the $\mathrm{Al}$ matrix decreases to $113 \mathrm{~nm}$. The crystallite size of the reinforcing phases is between 1.27 and $10.9 \mathrm{~nm}$ after $30 \mathrm{~h}$ of milling.

In the case of wet milling:

1. Ethanol as PCA not only decomposes during high-energy milling as it is known from the literature. Ethylene is formed during the dehydration of ethanol, and at the same time, the hydrogenation of ethylene to ethane and the oxidation of ethanol takes place in the system. 
2. Ethanol decomposes to carbon dioxide, water, and ethane during high-energy milling because all the necessary conditions, such as high temperature and catalysts (Al2O3 from the oxide layer, $\mathrm{Ni}$ from the balls and bowl, and hydrogen from the $\mathrm{Cu}-\mathrm{Zr}$ based particles) are provided in the course of Al milling with $\mathrm{Cu} 36 \mathrm{Zr} 48 \mathrm{Ag} 8 \mathrm{Al} 8$ alloy powder milling. The amorphous-nanocrystalline structure is formed thanks to these mechanochemical processes.

3. The amount of the amorphous phase increases from 0.1 to $10 \mathrm{wt} . \%$ after $30 \mathrm{~h}$ of milling owing to the reduction of the oxide layer by ethanol.

4. The crystallite size of the Al matrix is between 29 and $46 \mathrm{~nm}$ after $30 \mathrm{~h}$ of milling time. The crystallite size of the reinforcing phases varies from 5-200 $\mathrm{nm}$.

Funding: This research received no external funding.

Acknowledgments: This work was carried out as part of the GINOP-2.3.2-15-2016-00027 project implemented in the framework of the Szechenyi 2020 program. The realization of this project is supported by the European Union. The author would like to thank her present colleagues, who have contributed to the research on processing advanced materials using high-energy mechanical milling at the University of Miskolc. Courtesy to Innovacios Laboratorium Ltd., (Miskolc, Hungary) for the support of Field Emission Scanning Electron Microscope (SEM) Hitachi S-4800 equipped with Bruker AXS Energy-dispersive X-ray Spectrometer (EDS) system.

Conflicts of Interest: The authors declare no conflict of interest.

\section{References}

1. Han, Q.; Setchi, R.; Evans, S.L. Synthesis and characterisation of advanced ball-milled $\mathrm{Al}^{-} \mathrm{Al}_{2} \mathrm{O}_{3}$ nanocomposites for selective laser melting. Power Technol. 2016, 297, 183-192. [CrossRef]

2. Song, J.G.; Chen, L.; Xiang, Y.; Liu, Y.; Guo, X.S.; Zhang, X.L.; Guo, S.L.; Qin, Y.N. Effect of Sintering Temperature on the Densification Mechanism of Al2O3-Al Metal Ceramics via the Powder Metallurgy Method. Solid State Phenom. 2018, 279, 104-108. [CrossRef]

3. Shobha, R.; Siddaraju, C.; Suresh, K.; Niranjan, H. Mechanical Property Evaluation of Heat Treated Insitu AlTiB 2 Composite after Severe Plastic Deformation. Mater. Today Proc. 2018, 5, 2534-2540. [CrossRef]

4. Soltani, S.; Khosroshahi, R.A.; Mousavian, R.T.; Jiang, Z.Y.; Boostani, A.F.; Brabazon, D. Stir casting process for manufacture of Al-SiC composites. Rare Metals 2017, 36, 581-590. [CrossRef]

5. Huang, Y.; Bazarnik, P.; Wan, D.; Luo, D.; Pereira, P.H.R.; Lewandowska, M.; Yao, J.; Hayden, B.E.; Langdon, T.G. The fabrication of graphene-reinforced Al-based nanocomposites using high-pressure torsion. Acta Mater. 2019, 164, 499-511. [CrossRef]

6. Feng, S.; Guo, Q.; Li, Z.; Fan, G.; Li, Z.; Xiong, D.-B.; Su, Y.; Tan, Z.; Zhang, J.; Zhang, D. Strengthening and toughening mechanisms in graphene-Al nanolaminated composite micro-pillars. Acta Mater. 2017, 125, 98-108. [CrossRef]

7. Sadeghi, B.; Shamanian, M.; Cavaliere, P.; Ashrafizadeh, F. Effect of processing parameters on the microstructural and mechanical properties of aluminum-carbon nanotube composites produced by spark plasma sintering. Int. J. Mater. Res. 2018, 109, 900-909. [CrossRef]

8. Guo, B.; Zhang, X.; Cen, X.; Chen, B.; Wang, X.; Song, M.; Ni, S.; Yi, J.; Shen, T.; Du, Y. Enhanced mechanical properties of aluminum based composites reinforced by chemically oxidized carbon nanotubes. Carbon 2018, 139, 459-471. [CrossRef]

9. Capuzzi, S.; Timelli, G. Preparation and Melting of Scrap in Aluminum Recycling: A Review. Metals 2018, 8, 249. [CrossRef]

10. Zhang, W.; Hu, Y.; Wang, Z.; Yang, C.; Zhang, G.; Prashanth, K.; Suryanarayana, C. A novel high-strength Al-based nanocomposite reinforced with Ti-based metallic glass nanoparticles produced by powder metallurgy. Mater. Sci. Eng. A 2018, 734, 34-41. [CrossRef]

11. Karthik, G.; Panikar, S.; Ram, G.J.; Kottada, R.S. Additive manufacturing of an aluminum matrix composite reinforced with nanocrystalline high-entropy alloy particles. Mater. Sci. Eng. A 2017, 679, 193-203. [CrossRef]

12. Zhang, Z.; Elkedim, O.; Ma, Y.; Balcerzak, M.; Jurczyk, M. The phase transformation and electrochemical properties of TiNi alloys with $\mathrm{Cu}$ substitution: Experiments and first-principle calculations. Int. J. Hydrogen Energy 2017, 42, 1444-1450. [CrossRef] 
13. Kumar, A.; Swarnakar, A.K.; Basu, A.; Chopkar, M. Effects of processing route on phase evolution and mechanical properties of CoCrCuFeNiSix high entropy alloys. J. Alloy. Compd. 2018, 748, 889-897. [CrossRef]

14. Sun, C.; Hai, X.; Xi, S.; Fan, Z.; Li, P.; Wang, W. New insights of solid-state alloying and amorphous-nanocrystalline cyclic phase transitions during Cr-40wt.\%Mo powder milling. J. Alloy. Compd. 2018, 731, 667-677. [CrossRef]

15. Feizabad, M.H.K.; Sharafi, S.; Khayati, G.R.; Ranjbar, M. Effect of process control agent on the structural and magnetic properties of nano/amorphous $\mathrm{Fe}_{0.7} \mathrm{Nb}_{0.1} \mathrm{Zr}_{0.1} \mathrm{Ti}_{0.1}$ powders prepared by high energy ball milling. J. Magn. Magn. Mater. 2018, 449, 297-303. [CrossRef]

16. Wu, Z.; Liang, Y.; Fu, E.; Du, J.; Wang, P.; Fan, Y.; Zhao, Y. Effect of Ball Milling Parameters on the Refinement of Tungsten Powder. Metals 2018, 8, 281. [CrossRef]

17. Zhang, L.; Guo, X. Effects of Process Control Agents on the Mechanical Alloying Behavior of Nb-Ti-Si Based Alloy. Mater. Trans. 2018, 59, 528-534. [CrossRef]

18. Sarwat, S.G. Contamination in wet-ball milling. Powder Metall. 2017, 60, 267-272. [CrossRef]

19. Tikhov, S.F.; Valeev, K.R.; Salanov, A.N.; Cherepanova, S.V.; Boldyreva, N.N.; Zaikovskii, V.I.; Sadykov, V.A.; Dudina, D.V.; Lomovsky, O.I.; Romanenkov, V.E.; et al. Phase formation during high-energy ball milling of the ${ }_{33} \mathrm{Al}_{-45} \mathrm{Cu}-{ }_{22} \mathrm{Fe}$ (at. \%) powder mixture. J. Alloy. Compd. 2018, 736, 289-296. [CrossRef]

20. Wang, P.; Cai, H.; Zhou, S.; Xu, L. Processing, microstructure and properties of $\mathrm{Ni}_{1.5} \mathrm{CoCuFeCr}_{0.5-\mathrm{x}} \mathrm{V}_{\mathrm{x}}$ high entropy alloys with carbon introduced from process control agent. J. Alloy. Compd. 2017, 695, 462-475. [CrossRef]

21. Nazari, K.A.; Nouri, A.; Hilditch, T. The addition of a surfactant at regular time intervals in the mechanical alloying process. J. Alloy. Compd. 2014, 615, 47-55. [CrossRef]

22. Suryanarayana, C. Phase formation under non-equilibrium processing conditions: Rapid solidification processing and mechanical alloying. J. Mater. Sci. 2018, 53, 13364-13379. [CrossRef]

23. Neamţu, B.; Chicinaş, H.; Marinca, T.F.; Isnard, O.; Pană, O.; Chicinas, I.; Chicinas, H. Amorphisation of Fe-based alloy via wet mechanical alloying assisted by PCA decomposition. Mater. Chem. Phys. 2016, 183, 83-92. [CrossRef]

24. McCusker, L.B.; Von Dreele, R.B.; Cox, D.E.; LoueÈr, D.; Scardi, P. Rietveld refinement guidelines. J. Appl. Cryst. 1999, 32, 36-50. [CrossRef]

25. Bish, D.L.; Howard, S.A. Quantitative phase analysis using the Rietveld method. J. Appl. Crystallogr. 1988, 21, 86-91. [CrossRef]

26. Okamoto, H. Cu-Zr (Copper-Zirconium). J. Phase Equilibria Diffus. 2008, 29, 204. [CrossRef]

27. Abrosimova, G.E.; Aronin, A.S. Evolution of the amorphous-phase structure in metal-metal type metallic glasses. J. Surf. Investig. X-ray Synchrotron Neutron Tech. 2015, 9, 887-893. [CrossRef]

28. Suryanarayana, C. Mechanical alloying and milling. Prog. Mater. Sci. 2001, 46,1-184. [CrossRef]

29. Pajor, K.; Kozieł, T.; Cios, G.; Błyskun, P.; Bała, P.; Zielińska-Lipiec, A. Glass forming ability of the $Z_{50} \mathrm{Cu}_{40} \mathrm{Al}_{10}$ alloy with two oxygen levels. J. Non-Cryst. Solids 2018, 496, 42-47. [CrossRef]

30. Cole, K.; Kirk, D.; Singh, C.V.; Thorpe, S. Role of niobium and oxygen concentration on glass forming ability and crystallization behavior of $\mathrm{Zr}-\mathrm{Ni}-\mathrm{Al}-\mathrm{Cu}-\mathrm{Nb}$ bulk metallic glasses with low copper concentration. J. Non-Cryst. Solids 2016, 88-94. [CrossRef]

31. Lee, Y.; Jeon, J.; Nam, S.; Jang, T.; Kim, H.; Lee, M.; Kim, Y.; Yang, D.; Min, K.; Choi, H. Soft magnetic properties of Fe-based amorphous/nanocrystalline hybrid materials. Powder Technol. 2018, 339, 440-445. [CrossRef]

32. Lim, K.-R.; Kim, W.-T.; Kim, D.-H. Characterization of the Oxide Layer Formed on the Cu-Zr Based Metallic Glass during Continuous Heating. Appl. Microsc. 2012, 42, 174-178. [CrossRef]

33. Cui, J.; Li, J.; Wang, J.; Kou, H.; Qiao, J.; Gravier, S.; Blandin, J. Crystallization kinetics of $\mathrm{Cu}_{38} \mathrm{Zr}_{46} \mathrm{Ag}_{8} \mathrm{Al}_{8}$ bulk metallic glass in different heating conditions. J. Non-Cryst. Solids 2014, 404, 7-12. [CrossRef]

34. Zhang, W.; Zhang, Q.; Inoue, A. Fabrication of $\mathrm{Cu}-\mathrm{Zr}-\mathrm{Ag}-\mathrm{Al}$ glassy alloy samples with a diameter of $20 \mathrm{~mm}$ by water quenching. J. Mater. Res. 2008, 23, 1452-1456. [CrossRef]

35. Satta, A.; Shamiryan, D.; Baklanov, M.R.; Whelan, C.M.; Le, Q.T.; Beyer, G.P.; Vantomme, A.; Maex, K. The Removal of Copper Oxides by Ethyl Alcohol Monitored In Situ by Spectroscopic Ellipsometry. J. Electrochem. Soc. 2003, 150, G300-G306. [CrossRef] 
36. Belov, N.A.; Aksenov, A.A.; Eskin, D.G. Iron in Aluminium Alloys: Impurity and Alloying Element: Impurity and Alloying Element; CRC Press: London, UK, 2002. [CrossRef]

37. Gupta, R.K.; Murty, B.S.; Birbilis, N. An Overview of High-Energy Ball Milled Nanocrystalline Aluminum Alloys; Springer Briefs in Materials; Springer International Publishing: Cham, Switzerland, 2017.

(C) 2019 by the author. Licensee MDPI, Basel, Switzerland. This article is an open access article distributed under the terms and conditions of the Creative Commons Attribution (CC BY) license (http://creativecommons.org/licenses/by/4.0/). 